\title{
Grammar Profiling: Realignment of CEFR Teaching Materials and Assessments
}

\author{
Fazillah Sulaiman $^{1 *}$, Surinder Kaur Satwant Singh ${ }^{2}$ \\ ${ }^{1}$ Universiti Pertahanan Nasional Malaysia, Kem Sungai Besi Kuala Lumpur, Malaysia \\ ${ }^{1,2}$ Language Centre, Universiti Pertahanan Nasional Malaysia, MALAYSIA. \\ Corresponding author*
}

\begin{abstract}
This study investigates the effectiveness and the role of grammar profiling in the realignment of teaching and assessment of grammar as an explicitly taught subject based on the Common European Framework of Reference for Languages or CEFR. This study utilised a quantitative analysis involving fifty students from the Basic Grammar and Vocabulary (LLE 3012) class at the National Defence University of Malaysia (NDUM). The students were assessed on their grammar knowledge and communication skills. The students took the track test at the beginning of the semester to evaluate their grammar knowledge, whereby their results were recorded. The results were later categorisedto six levels namely A1 (Beginner), A2 (Elementary), B1 (Pre-intermediate), B2 (Intermediate), C1 (Upperintermediate) and C2 (Advanced). Then, the teaching and learning process took place for fourteen weeks using the grammar profiling syllabus. At the end of the fourteenth week, the students retook the track test. As for their communication skills, the studentsrecorded a presentation about themselves at the beginning and at the end of the semester. The presentations were evaluated using the CEFR Self-Assessment Grid (Spoken Production). The data were analysed using the paired sample $t$ test and it was found that for both assessments the mean value for the pretest was lower compared to the value obtained from the posttest. This indicates that the teaching and learning process using the grammar profiling syllabus was considered a success in terms of guiding instructors to align their assessment strategies and knowledge according to the newly aligned CEFR proposed benchmarked descriptors.
\end{abstract}

Keywords: CEFR; communication; grammar profiling; proficiency; Tracktest

\section{INTRODUCTION}

$\mathrm{T}$ The Common European Framework of Reference for Languages or CEFR was introduced in 2001. CEFR was designed to establish international standards for foreign language education and to accommodate the requirements of language learners. The introduction of this framework was done with a basic idea of restricting and realigning the existing benchmark used in second language teaching and learning, specifically in terms of assessment and materials. The rubrics provide a basic guide for instructors to design and develop instructional as well as assessment materials along with descriptors that can be used to evaluate students' overall progress in their language. The framework was initially developed with a basic six level tier of descriptors that can be specifically used to organise learners according to their ability and mastery of the English language. These descriptors are specific and more targeted at learners 'overall communicative ability in general. The framework is grouped mainly according to three categories: Proficient users (levels C1 \& C2), Independent users (levels B1 \& B2) and Basic users (levels A1 \& A2). In addition to these categories and descriptors, there are also additional and detailed "can do" statements for other skills which are more detailed. For example, for "Grammar", a student at the A1 level is expected to have mastered their basic Nouns and Pronouns by recognition. This same application is used for a list of other relevant skills in language learning.

The Ministry of Education was all set to raise the standards of the English language proficiency of Malaysian students. This was mainly their initiative to produce students who were not only proficient in the language but also to address the issue of lack of confidence, lack of oral communication skills as well as a lack of communicative competence which was already becoming a common issue reported as a main reason that contributed to greater graduate unemployability (HazitaAzman, 2016). Thus, a council was formed to introduce this framework at all levels, most importantly at schools, followed by the tertiary language learning platforms. The introduction of the framework was also mainly done not only to address the issue of standardisation and benchmarking, however the CEFR encouraged a much more aligned syllabus in accordance with the current Malaysia Education Blueprint. It was ensured that the Malaysian English language teaching and learning were on par with existing international English language teaching and learning standards (HazitaAzman, 2016). The suggested roadmap which had begun in 2013 proposed a long journey of restructuring and realignment and is expected to be completed in 2025. In other words, by Year 2025, the CEFR framework would have been adopted and used as a benchmark in the teaching and learning of English at all levels. This study aims at exploring the realignment of the existing grammar syllabus via grammar profiling at a selected tertiary institution, investigating the possibility of incorporating the CEFR benchmarking into the existing tertiary English Language syllabus; in this context specifically addressing the teaching and learning of grammar as a skill. At the same time, this study will also explore the students communicative performance using the new CEFR aligned materials and rubrics. 


\section{LITERATURE REVIEW}

\section{Introduction to CEFR}

The CEFR framework has been actively introduced and is now a common concept in English Language teaching and learning across the globe. Many large countries such as Japan, Taiwan and China, haveapplied this framework into their existing English syllabus. According to Bucar et. Al (2014), in Taiwan, CEFR was mapped against several English proficiency tests such as General English Proficiency Test (GEPT). IELTS, TOEFL and TOEIC. Similarly, in Japan the CEFR has been used exclusively in the development of teaching materials, syllabus as well as assessment in their overall teaching and learning. In another separate study by $\mathrm{Wu}$ and $\mathrm{Wu}$ (2012), it was observed that the realignment of syllabus and curriculum had become much more standardised following the introduction of this framework. This study mainly analysed the effectiveness of the CEFR framework in terms of assessments, challenges that were faced as well as the present status of the English language teaching and learning after adopting the framework into their curriculum design. Although the outcomes were mainly positive, it was noted that the implementation of the framework required much effort and there were several challenges that had to be met during the entire process.

\section{The Implementation of CEFR in Malaysia: Issues and Challenges}

In addition to other countries such as Thailand, Vietnam, and Korea, the CEFR influence was also prominent in terms of its impact on the overall English Language teaching and learning syllabus and curriculum design in Malaysia. Interestingly, in a study conducted by Lo (2018), many language instructors and educators reported cases of anxiety towards the implementation of this framework, despite various courses, workshops and training done both at primary and secondary levels to equip educators with the knowledge they needed. In the study, around 200 secondary school English teachers admitted having understood the framework well and were familiar with the descriptors, however these teachers still expressed concern and anxiety towards its 'overall implementation.They were mainly unsure of their roles and some claim to have lack of information on the framework itself (Lo, 2018).

In another study involving public universities, a total of 170 instructors claimed that they were unsure how the framework would fit into their existing syllabus, as most universities had already developed their respective teaching curriculum and documents. This was also a challenge as many universities had their individual teaching syllabus and curriculum and the lack of standardisation had made it even harder for the framework to be implemented (RamiaidaDarmie et al., 2017). The findings from this study also revealed that although the framework has been successfully adopted and used by other Asean countries, Malaysia needs more research to make the
CEFR more effective. At present, the Malaysian government has taken a bold decision to implement this framework to improve the English proficiency of its students (ZuraidaMohd Don 2015), however until the educators and instructors are not able to be completely confident with its 'implementation, the success of this framework cannot be guaranteed. This study, therefore, investigates the possibility of aligning Grammar as a skill into the existing curriculum and syllabus of the university with hopes to compare students 'overall performance using the new re-aligned syllabus as well as assessments put together by the English Language Unit against the CEFR framework.

\section{Teaching Grammar and Communication Skills}

Grammar is the most challenging part in language learning (Jalali\&Dousti, 2012). In order to develop linguistic proficiency, learning grammar is one of the important language features (Yule, 2010). Yule (2010) also added that to be proficient in grammatical rules, students are able to form words and sentences accurately with correct structure. According to AnisFirdatulRochma et al. (2020), by teaching grammar the students will improve their communication skills at the same time. Ellis (1992) also mentioned that teaching grammar is not only explaining the rules, but also trained the students to communicate effectively. The language instructors should create activities for learning grammar in a way that not only the students could master the grammar knowledge but at the same time they are able to communicate effectively. We can teach grammar using the traditional method or involving technology in the grammar learning activities (Ahmad et al., 2018). Technology can involve watching videos or role playing. Exposing students to communicate in grammar class will help the students to improve in their grammar proficiency and at the same time the grammar rules that they learnt can be lifelong (Spada, 1997). Teaching grammar using with communication and materials will help the students to be more positive in learning grammar and they are able to be practical as well as they can practice their communication skills with good grammar outside the classroom (Zari Saeedi\&AsoBiri, 2016; Celce-Murcia, 2002).

\section{Grammar Profiling and CEFR Self-Assessment Grid}

Grammar profiling is used to evaluate the students' level of proficiency, specifically in grammar. Grammar profiling as presented by the basic descriptors of the CEFR sixlevels: namely A1 (Beginner), A2 (Elementary), B1 (Preintermediate), B2 (Intermediate), C1 (Upper-intermediate) and C2 (Advanced). As the students move up to each level, they develop competence in grammatical forms and meaning. Each level provides a typical world-wide grammar profile. Grammar profiling is the sub-project of English Profiling and the objective of the Grammar profiling is to profile students' ability in grammar (O'Keeffee and Mark, 2017). In general, below is the illustration of the grammar accuracy taken from the proposed Common European Framework of Reference for Languages: Learning, Teaching, Assessment. 


\begin{tabular}{|c|l|}
\hline C2 & $\begin{array}{l}\text { Maintains consistent grammatical control of complex } \\
\text { language, even while attention is otherwise engaged (e.g. } \\
\text { in forward planning, in monitoring others' reactions). }\end{array}$ \\
\hline \multirow{2}{*}{ C1 } & $\begin{array}{l}\text { Consistently maintains a high degree of grammatical } \\
\text { accuracy; errors are rare and difficult to spot. }\end{array}$ \\
\hline \multirow{3}{*}{ B2 } & $\begin{array}{l}\text { Good grammatical control; occasional 'slips' or non- } \\
\text { systematic errors and minor flaws in sentence structure } \\
\text { may still occur, but they are rare and can often be } \\
\text { corrected in retrospect. }\end{array}$ \\
\cline { 2 - 3 } & $\begin{array}{l}\text { Shows a relatively high degree of grammatical control. } \\
\text { Does not make mistakes which lead to misunderstanding. }\end{array}$ \\
\hline \multirow{3}{*}{ B1 } & $\begin{array}{l}\text { Communicates with reasonable accuracy in familiar } \\
\text { contexts; generally good control though with noticeable } \\
\text { mother tongue influence. Errors occur, but it is clear what } \\
\text { he/she is trying to express. }\end{array}$ \\
\cline { 2 - 3 } & $\begin{array}{l}\text { Uses reasonably accurately a repertoire of frequently used } \\
\text { 'routines' and patterns associated with more predictable } \\
\text { situations. }\end{array}$ \\
\hline A2 & \begin{tabular}{l} 
Uses some simple structures correctly, but still \\
\hline
\end{tabular} \\
\hline
\end{tabular}

\begin{tabular}{|l|l|}
\hline & $\begin{array}{l}\text { systematically makes basic mistakes - for example tends } \\
\text { to mix up tenses and forget to mark agreement; } \\
\text { nevertheless, it is usually clear what he/she is trying to } \\
\text { say. }\end{array}$ \\
\hline A1 & $\begin{array}{l}\text { Shows only limited control of a few simple grammatical } \\
\text { structures and sentence patterns in a learnt repertoire. }\end{array}$ \\
\hline
\end{tabular}

Source: (CEFR pg, 114)

Students need to achieve certain grammatical criterial features at each level. The table below shows the summary of grammatical criterial features, with example utterances that distinguish each student at every level. There are no grammatical criterial features provided for level A1 as there is an investigation going on for this level regarding the features.

\begin{tabular}{|c|c|c|}
\hline Level & Some key features & Examples from the CLC at the appropriate level \\
\hline A2 & 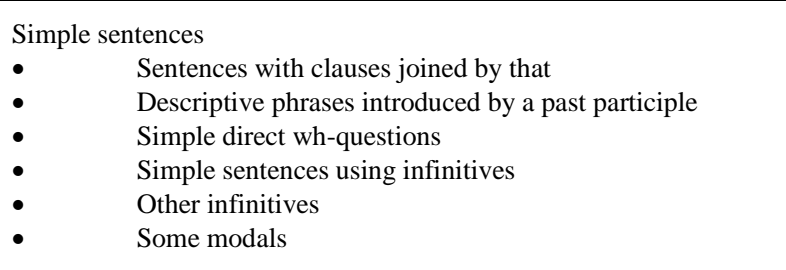 & $\begin{array}{l}\text { - We came back and went to bed } \\
\text { - } \quad \text { I know that you have a new house too } \\
\text { There are beautiful paintings painted by famousIranian } \\
\text { painters } \\
\text { - What are you going to wear? } \\
\text { - I want to buy a coat } \\
\text { - We mething to eat } \\
\text { - We must be there at } 7 \text { o'clock in the morning. }\end{array}$ \\
\hline B1 & $\begin{array}{ll}\text { - } & \text { ing clauses } \\
\text { - } & \text { Whose relative clauses } \\
\text { - } & \text { Indirect questions } \\
\text { - } & \text { Clauses with what as subject/object } \\
\text { - } & \text { Verb+object+infinitive } \\
\text { - } & \text { easy + infinitive } \\
\text { - } & \text { Some complex auxiliaries } \\
& \text { Additional modal uses }\end{array}$ & $\begin{array}{l}\text { - Maria saw him taking a taxi } \\
\text { - } \quad \text { this famous painter whose pictures I like so much } \\
\text { - } \quad \text { This is where it is? } \\
\text { - } \quad \text { I ordered him to gather my men. } \\
\text { - The train station is easy to find. } \\
\text { - } \quad \text { would rather, had better } \\
\text { I have invited all his friends, so we should be } 28 \\
\text { people. }\end{array}$ \\
\hline B2 & $\begin{array}{ll}\text { - } & \text {-ing clause before the main clause } \\
\text { - } & \text { It + verb }+ \text { infinitive phrase } \\
\text { - } & \text { Wh-clause as subject of main clause } \\
\text { - } & \text { Reported speech } \\
& \text { Lexically-specific verbs/adjectives + infinitive }\end{array}$ & $\begin{array}{l}\text { - Talking about spare time, I think we could go to the } \\
\text { Art Museum } \\
\text { - It would be helpful to work in your group as well. } \\
\text { - What came after was what really changed my summer! } \\
\text { - I told him I loved his songs. } \\
\text {... proved to be wrong, turned out to be ...,expected to } \\
\text {... }\end{array}$ \\
\hline $\mathrm{C} 1$ & $\begin{array}{l}\text { - } \\
\text { Mexically-specific verbs }+ \text { object }+ \text { infinitive } \\
\text { Might for permission } \\
\text { Fewer grammatical errors with agreement, countability or } \\
\text { word formation }\end{array}$ & $\begin{array}{l}\text { - I believe her to be this country's best representative. } \\
\text { - Might I tell you what we [should/will] discuss? }\end{array}$ \\
\hline $\mathrm{C} 2$ & $\begin{array}{ll}- & \text { Some new lexically-specific verbs + object+infinitive } \\
\text { - } & \text { Longer utterances with greater accuracy }\end{array}$ & $\begin{array}{l}\text { They declare some products to be the hits of the } \\
\text { season }\end{array}$ \\
\hline
\end{tabular}

Source: (English Profile pg, 11)

As for the communicative performance in the context of CEFR, activities that been conducted can be divided into reception, production, interaction and mediation (CEFR, p.14). In this paper, the focus is on 'production', hence the descriptors matched accordingly to the rubrics suggested. Below is the CEFR Self-Assessment Grid on spoken production.

\begin{tabular}{|c|c|}
\hline \multicolumn{2}{|c|}{ Spoken Production } \\
\hline A1: Basic User & $\begin{array}{c}\text { I can use simple phrases and sentences to describe } \\
\text { where I live and people I know. }\end{array}$ \\
\hline A2: Basic User & I can use a series of phrases and sentences to \\
\hline
\end{tabular}

\begin{tabular}{|c|c|}
\hline & $\begin{array}{l}\text { describe in simple terms my family and other } \\
\text { people, living conditions, my educational } \\
\text { background and my present or most recent job. }\end{array}$ \\
\hline B1: Independent User & $\begin{array}{l}\text { I can connect phrases in a simple way in order to } \\
\text { describe experiences and } \\
\text { events, my dreams, hopes and ambitions. I can } \\
\text { briefly give reasons and explanations for opinions } \\
\text { and plans. I can narrate a story or relate the plot of } \\
\text { a book or film and describe my reactions. }\end{array}$ \\
\hline B2: Independent User & $\begin{array}{l}\text { I can present clear, detailed descriptions on a wide } \\
\text { range of subjects related to my field of interest. I } \\
\text { can explain a viewpoint on a topical issue giving } \\
\text { the advantages and disadvantages of various } \\
\text { options. }\end{array}$ \\
\hline
\end{tabular}




\begin{tabular}{|c|c|}
\hline C1: Proficient User & $\begin{array}{c}\text { I can present clear, detailed descriptions of } \\
\text { complex subjects integrating sub-themes, } \\
\text { developing particular points and rounding off with } \\
\text { an appropriate conclusion. }\end{array}$ \\
\hline C2: Proficient User & $\begin{array}{c}\text { I can present a clear, smoothly-flowing description } \\
\text { or argument in a style appropriate to the context } \\
\text { and with an effective logical structure which helps } \\
\text { the recipient to notice and remember significant } \\
\text { points. }\end{array}$ \\
\hline
\end{tabular}

Source: (CEFR Self AssessmentGrid )

Theoretical Framework

\section{Communicative Language Teaching}

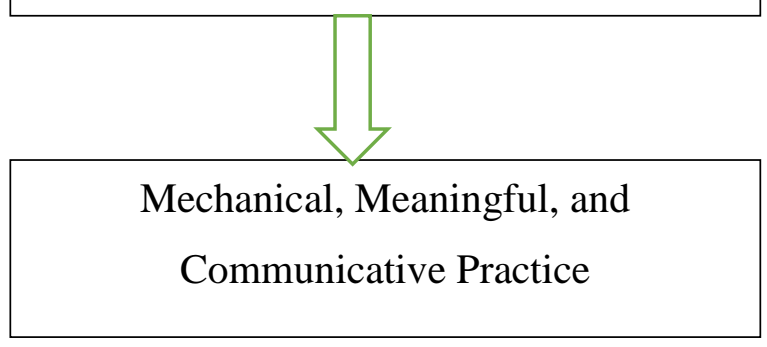

This study utilizes the Communicative Language Teachingtheory. This is only apt and synonymous with the nature of the CEFR descriptors which places a huge emphasis on the spoken or communicative aspect mainly. For this study, the spoken task was set based on a list of threedifferent practices which includes mechanical, meaningful, and communicative practices (Richards, 2006). As Richards (2006) pointed out, mechanical practice involved drills and repetition, meaningful practice involved responding and describing whereas communicative practice focused on the communicative abilities that were demonstrated by the students. The task therefore fits the proposed Communicative Language Teachingapproach which clearly emphasises on "communicative proficiency rather than mere mastery of structures" (Richards and Rogers, 1986:64).

\section{METHODOLOGY}

This study isquantitative, and it involves 50 students as participants from various faculties, namely Centre of Defence Foundation, Medical Foundation, Faculty of Engineering, Faculty of Sciences and Defence Technology, Faculty of Studies and Defence Management, Language Centre and AkademiKecergasanPertahanan. Students who scored Band 1 and Band 2 for their Malaysian University English Test (MUET) were asked toenroll themselves in the Basic Grammar and Vocabulary (LLE 3042) class at the universityto fulfill the requirement set by the Ministry of Education. At the beginning of the semester, the students were asked to take an online test. Track test is an online English proficiency test that was launched in 2012 and has been extensively used to measure various English language proficiency skills, especially amongst Non-native English language speakers. This test provides students with a specific level on their performance based on the Common European Framework of Reference for Language (CEFR) descriptive scores or aggregates upon completion. There are six levels namely; A1 (Beginner), A2 (Elementary), B1 (Preintermediate), B2 (Intermediate), C1 (Upper-intermediate) and C2 (Advanced). The results of the pretest were recorded. The students were then taught and assessed using the materials and rubrics that were realigned according to the suggested CEFR based curriculum and profiling. The teaching, learning and assessment process took place for fourteen weeks using the grammar profile in terms of material and rubric assessment. The aligned rubrics were done according to the set CEFR global scale rubrics that was already available. The rubrics were realigned and adjusted to be more specific in terms of assessing students' overall can do's according to their knowledge and application of grammar, especially in a spoken context. The teaching and learning process utilises the materials and the Communication Language Teaching method. In the beginning of the class, a particular topic is being introduced. Students are then required to carry out the tasks given on a given topic. Using a set of suggested words, students were later asked to describe and respond on the questions given by their lecturer and classmates.At the end of the fourteenth week, the students were given the same tracktest and the results from the posttest were recorded.

As for the communicative performance, the students were asked to submit a link of a video recorded whereby they were asked to introduce themselves by speaking and sharing about their background, personality, likes, dislikes, and other relevant details. As for the pretest assessment, the video was to be submitted by the second week of the semester. As for the posttest, the same communicative performance video was asked to be submitted on the fourteenth week of the semester. Both videos were later evaluated based on the re-aligned CEFR Self-Assessment Grid (Spoken Production). The evaluation has six levels, and the levels are A1 and A2 (Basic User), B1 and B2 (Independent User) and C1 and C2 (Proficient User).

The results obtained were later analysed using paired sample t-test via the (SPSS) version 23, whereby the means of the two samples obtained were validated.

\section{DATA ANALYSIS}

Table 1 below shows the findings of the study. It is revealed that the mean for the Tracktest and communication performance pretest is 2.28 and 3.18 while the mean for theTracktest and communication performance posttest is 3.34 and 4.05. Since both,the mean value of the post-test is higher compared to the mean of the pre-test, using the materials and rubricsthat been taught to the students. The teaching has proven that the post-test grades of the students had improved. The study yieldedstatistically significant results as the p-value obtained was .001 (p-value is less than .005) 
Table 1 :Paired Sample t-test for the Pretest and Posttest

\begin{tabular}{|c|c|c|c|c|c|c|}
\hline & & $\mathrm{n}$ & Mean & $\begin{array}{c}\text { Std. } \\
\text { Deviati } \\
\text { on }\end{array}$ & $\begin{array}{l}\text { Correlati } \\
\text { on }\end{array}$ & $\begin{array}{c}\text { Significa } \\
\mathrm{nt}\end{array}$ \\
\hline \multirow{2}{*}{ Tracktest } & Pretest & \multirow{4}{*}{50} & 2.28 & .927 & \multirow{2}{*}{.725} & \multirow{4}{*}{.001} \\
\hline & Posttest & & 3.34 & 1.222 & & \\
\hline \multirow{2}{*}{$\begin{array}{l}\text { Communicat } \\
\text { ive } \\
\text { Performance }\end{array}$} & Pretest & & 3.18 & .941 & \multirow{2}{*}{.894} & \\
\hline & Posttest & & 4.02 & .845 & & \\
\hline
\end{tabular}

\section{DISCUSSION AND CONCLUSIONS}

It has been found that the teaching method and teaching materials of the CEFR grammar profiling didguide the students to perform better in the posttest as the mean of the posttest is higher compared to the pretest for both the tracktest and communicative performance. The teaching materials of the grammar profiling consist of twelve units, including nouns and pronouns, verbs (lexical and auxiliary), verb tenses, adjectives and adverb, preposition, conjunctions, phrases and clauses, sentence types, transformations, word meanings, synonyms and antonyms, root words one-word substitutes, phrasal verbs and idioms and words games-vocabulary development. These topics were taught for fourteen weeks to the students who took the Basic Grammar and Vocabulary (LLE 3042) class.

The assessment descriptors for assessing students' spoken production on the other hand was adopted directly and adapted according to the current global CEFR scale used. The findings had also indicated a significant consistency, as both tests recorded results that revealed improvement in terms of assessments as well as the content of the subject that the students were assessed on.

In every topic,the students were able to develop their communication skills by using words in the lesson (AnisFirdatulRochma et al., 2020; Ellis, 1992).As the pretest's mean is lower compared to the posttest, the teaching and learning process managed to improve their knowledge on the specific subject and proficiency in their communication skills. It is safe to infer that, looking at students' overall results, the students had viewed the teaching and learning process positively (Zari Saeedi\&AsoBiri, 2016; Celce-Murcia, 2002). It is recommended that for future study using technology in teaching and learning process can be a part of the research as perhaps it canmotivate the students to perform well in the assessments given. The researchers hope that the findings from this study will benefit and inspire other relevant and related tertiary research.

\section{REFERENCES}

[1] Anis Firdatul Rochma, SutrisnaWibama \& Basikin (2020). "The classroom management approach in the grammar practice class",
Journal of English Language Teaching and Linguistics, 5 (1), pp 91-104.

[2] Bucar, C. S., Ryu. H., Skof, N. M. \&Sangawa, K.H. (2014). "The CEFR and teaching Japanese as a foreign language, Linguistica, 54(1), pp 455-469.

[3] Celce-Murcia, M. (2002). Why it makes sense to teach grammar in context and through discourse. In E. Hinkel\& S. Fotos (eds.), New Perspectives on Grammar Teaching in Second Language Classrooms (pp. 119-134). Mahwah, NJ: Erlbaum

[4] Celik, S. (2013). "Plurilingualism, pluriculturalism, and the CEFR: Are Turkey's foreign language objectives reflected in classroom instruction", Social and Behavioral Sciences Journal. 70(25), pp 1872- 1879.

[5] Common European Framework of Reference for Languages: Learning, Teaching, Assessment Language Policy Unit, Strasbourg. Available: www.Coe.Int/Lang-Cefr

[6] Ellis, R. (1992). Second Language Acquisition and Language Pedagogy.Clevedon: Multilingual matters Ltd.

[7] HazitaAzman. (2016). "Implementation and challenges of English language education reform in Malaysian primary schools. $3 L$ : The Southeast Asian Journal of English Language Studies. 22(3), pp 65-78.

[8] Jalali, S., \&Dousti, M. (2012). "Vocabulary and grammar gain through computer educational games", GEMA Online Journal of Language Studies,pp 1077-1088.

[9] Lo, Y. Y. (2018). "English teachers' concern on Common European Framework of Reference for Languages (CEFR): An application of CBAM", JurnalKurikulumdanPengajaran Asia Pasifik, 6(1). Pp 46 -58.

[10] Maxwell, D. (2015). Thai schools adopt European framework to boost English language proficiency. Asian Correspondent Online: Education Section. Available: https://asiancorrespondent.com/2015/04/thai-schools-adopteuropean-framework-to-boost-englishlanguage-proficiency

[11] Nguyen, V.H. \& Hamid, M.O. (2015). "Educational policy borrowing in a globalised world: A case study of Common European Framework of Reference for Languages in a Vietnamese university", Journal of English Teaching, Practice \& Critique, 14(1), pp 60-74.

[12] RamiaidaDarmi, Noor Saazai Mat Saad, Norhana Abdullah, FarizaPutehBehak, ZarinaAshikinZakaria\& Juliana Niza Ismail Adnan. (2017). Teachers' views on students' performance in English language proficiency courses via CEFR descriptors. IJAEDU-International E-Journal of Advances in Education, 3(8), pp 363-370.

[13] Richards, J.C. and Rodgers, T. 1986. Approaches and Methods in Language Teaching: A Description and Analysis. Cambridge: Cambridge University Press

[14] Richards, J. C. (2006). Communicative Language Teaching Today. Cambridge: Cambridge University Press

[15] Spada, N. (1997). Form-focused instruction and second language acquisition: A review of classroom and laboratory research, Language Teaching, 30(2), pp 73-87.

[16] Wu, J. R.W \& Wu, R.Y.F. (2012). "GEPT and English language teaching and testing in Taiwan", Language Assessment Quarterly. 9(1), pp 11-25.

[17] Yule, G. (2010). The Study of Language. UK: Cambridge University Press.

[18] Zari Saeedi\&AsoBiri (2016). "The application of technology in teaching grammar to EFL learners: The role of animated sitcoms", Teaching English with Technology, 16(2), pp 18-39.

[19] ZuraidahMohd Don. (2015). English language proficiency, graduate employability and the role of CEFR. ASEAN Seminar 2015 on "Best Practices in English Teaching in ASEAN Universities". UM repository. 